\title{
POLITICAL PARTICIPATION OF WOMEN IN GRAMPANCHAYAT OF ODISHA-A STUDY
}

\author{
Kamalakanta Panda \\ Lecturer in Pol.SC, Trupti Women's (Degree) College Basudevpur, Bhadrak, \\ Research Scholar, North Orissa University, India \\ Dr. Madhusudan Sahoo \\ Ex-Register, North Orissa University, India
}

\begin{abstract}
The present study attempts to study the extent of the political participation of women in the functioning as well as the electoral process of panchayats and their problems. The study was conducted in july 2018 using a sample of 80 women respondents from kharida Binayakpur Gram Panchyat of Basudevpur Block in Bhadrak District of Odisha. The findings of the study revealed that political participation of women in the electoral process of the panchyat is rather satisfactory, but sofar as assembly and parliament elections are concerned women have great apathy towards politics. The mala dominated society, culture and low level of education are greatly responsible for the back wardness of women.
\end{abstract}

Keywords: Women, Empowerment, Political participation.

Cite this Article: Kamalakanta Panda and Dr. Madhusudan Sahoo, Political Participation of Women in Grampanchayat of Odisha-A Study, Journal of Management (JOM), 6 (6), 2019, pp. 29-36.

http://www.iaeme.com/JOM/issues.asp?JType=JOM \&VType=6\&IType=6

\section{INTRODUCTION:}

Political Participation simply refers to the way through which the citizens of a country take part in the electoral as well as in policy making process. In other words, political participation is a way or a process through which the aspirations and needs of the people can be represented. Generally, the term "political participation" refers to those voluntary activities by which members of a society share in the selection of rules and directly or indirectly in the formation of public policy.

These activities include casting votes, seeking information, holding discussion, attending meeting, staging strikes and demonstrations, communicating with the legislators and the like. Women constitute more or less than half of the population of any country. But their involvement in politics is insignificant compared to men. Many psychological, social and physical factors hold women back from active political involvement. This is true as far as the State and National level politics is concerned. A democratic country cannot progress if energies of its half 
population are concerned in the kitchen only. Indian constitution ensures gender equality through various and regulations. It was presumed that these rights would automatically get translated in to political development of the women in the country. Women constitute a little less than $50 \%$ of the state's total population. Their socio-economic status is however, relatively low and they are discriminated against in all walks of life. For centuries, women have been confined to the home suppressed and deprived of their right to get fair treatment from the male dominated society.

The issue of women's participation in politics cannot be viewed in isolation from the general position of women in a society but despite their vast strength women occupy a marginalized position in the political system. According to Herbert Mc. Closky, "Participation is the principal means by which consent is granted or with drawn in a democracy and the rulers are made accountable to the ruled". Political philosophers like J.S mill, Rousseau and Bentham have strongly advocated the need for participation of people in different spheres of political life. As Noorjahan Bava puts it "direct and indirect participation of citizen in public affairs is the

Lifeline of a participatory democracy" In this Gram panchyat members are leading in economic planning, agriculture and resource development, education and health monitoring, house holding industry monitoring, animal husbandry etc.

\section{OBJECTIVE OF THE STUDY}

1. To know about how far and to what extent, the rural women participate in different spheres of activities ranging from decision making to exercising the right to vote in the Gram Panchyat.

2. To know the leadership qualities of women.

3. To explore the willingness of women representatives in the electoral process of panchayati Raj system.

\section{REVIEW OF LITERATURE}

Snehalata Panda (1996) in her study of village panchyat in Orissa found that women entered into politics due to mandatory provision of reservation. Most of the women are from nonpolitical background and entered into politics due to persuasion by their family members or pressure from the village community.

The important aspect of her study is that the women who reluctantly enter into politics showed great maturity in outlook, enthusiasm, increasing political consciousness and increasing perception of their role and responsibility.

Bidut Mohanty (2000) in her article" Women and political empowerment" ISS New Delhi mentions that empowerment has been defined as the change of self perception through knowledge. She clarifies the multiple purpose of reservation. It has not only aimed to improve only the member of elected leaders from weaker sections earlier poorly represented but also improved their economic independence, access to resources, access to education. This executes what is started as empowering women.

R.C. Agrawal (2005) in his paper "Women and panchayatiraj institution" revealed that there are various factors which discouraged the participation of women in rural local governance system. These are criminalization of politics, lack of safety and security, lack of initative, ignorance and lack of training, awareness about powers and duties and lack of adequate leadership Quality.

P. Patnaik (2005) finds out the participation of elected representatives belonging to weaker sections in the functioning of four-gram panchayats in odisha's Dhenkanal district, in order to 
observe the extent to which numerical representation has been successful in actual exercise of power by these sections.

The extent to which numerical representation has been successful in actual exercise of power by these sections.

Swain, jharana (1994) in her study titled "Emerging women Leadership in panchayatiraj A study in Balipatana block of khurda district in Odisha" reveals that how women are emerging as leaders of rural local governance institutions due to their participation In local governance system in large number. She has pointed that the enabling statutory provision encouraged women to participate in the rural local governance in large number.

\section{METHODOLOGY AND SAMPLE COVERAGE}

The present study is mostly based on empirical methods. Schedules were employed to collect data from the sample respondent. I also conducted personal interviews with the women respondents. Data were collected from secondary sources like census reports, government documents, gazettes, district handbook and other published literatures. As it is impossible to study the political participation of all women of the district I selected only one Grampanchayat of Basudevpur block in Bhadrak District.

\section{PROFILE OF THE GRAM PANHAYAT}

Kharida Binayakpur is a small Gram panchayat in Basudevpur Block of bhadrak District. There are three main revenue village under this G.P. this panchayat consists of 13 wards comprise of 15 villages. According to 2011 census, total population 7598, male, female ratio 52:99:47.01, total SC population 1969, total ST population 03, total OBC population 5,120, total General population 506 is seen in this area. The Gram panchayat is situtated on national Highway No. $60,35 \mathrm{~kg}$ from Bhadrak and $125 \mathrm{~kg}$ from the state capital Bhubaneswar. The total geographical area of the village is around 225 acres, of which only 47 acres are used for th village settlement, of the settled area 178 acres are used for agricultural purposes. The main sources of irrigation are submersible pumps seat. About sixty acres of land is not cultivatable because of lack of irrigation facilities. The main crops grown in the village are rice, wheat, vegetables and other oil seeds. The village irrigation mostly depends upon submersible pumps although there are lakes they are not suitable for agriculture.

The village has a primary school, High school, an Anganeadi Center, a Gram panchayat building, temples, a library, a branch post office, four hand operated bore wells and how changed them in to submersible pump seat by attaching single phase motors, three submersible pumps sets one major drinking water tank (capacity 75,000 liter) and three minor water tanks for drinking water. The village got an electricity supply as late as 1980. It has a total road length of $6 \mathrm{~kg}$ of which $2 \mathrm{~kg}$ road is constructed from cement and concrete.

\section{SOCIAL-ECONOMIC PROFILE OF THE RESPONDENTS}

While studying the socio-economic background of the respondent's age, education occupations are taken as important factors.

Table 1: Age wise distribution of respondents: N= 80

\begin{tabular}{|c|c|c|}
\hline Age group & Number & Percentage (\%) \\
\hline Young age (21-35) & 25 & $31.25 \%$ \\
\hline Middle Age(36-50) & 40 & $50 \%$ \\
\hline Aged (above 50) & 15 & $18.75 \%$ \\
\hline Total & 80 & $100 \%$ \\
\hline
\end{tabular}

(Source: personal communication / survey) 
The above table shows that majority of the women were the middle-aged category $(50 \%)$ followed the young age category $(31.25 \%)$ those who participated in panchayat elections and panchayat affairs. Only 18.755 were from aged category. It is quite clear from the above data that the aged women have some sort of apathy toward politics where as young and middle-aged women are more interested in politics.

Table 2: Caste wise distribution of the respondents: $\mathrm{No}=(80)$

\begin{tabular}{|c|c|c|}
\hline Caste & Number & Percentage (\%) \\
\hline General & 15 & $18.75 \%$ \\
\hline SC & 55 & $68.75 \%$ \\
\hline ST & 00 & $00.00 \%$ \\
\hline OBC & 10 & $12.5 \%$ \\
\hline Total & 80 & $100 \%$ \\
\hline
\end{tabular}

(Source: Personal communication/ survey)

From the above table it is found that majority of the women participated in the electoral process from the SC category (68.75\%) following by General Category (18.75\%) and no women participated from ST category so, the women of OBC and General category are less interested in politics so far as their social, cultural, educational and economical condition is concerned.

Table 3: Educational qualification of the respondents (No-80)

\begin{tabular}{|l|c|c|}
\hline \multicolumn{1}{|c|}{ Educational Qualification } & Number & Percentage \% \\
\hline Illiterate & 10 & $12.5 \%$ \\
\hline Primary & 30 & $37.5 \%$ \\
\hline Middle & 25 & $31.25 \%$ \\
\hline High school and above & 15 & $18.75 \%$ \\
\hline Total & 80 & $100 \%$ \\
\hline
\end{tabular}

(source: personal communication/ survey)

The data of above table shows that majority of women were primary level (37.5\%) followed by middle level (31.25\%) illiterate (12.5\%) and only (18.75\%) to High school level and 5\% had a graduate and or post-graduate education. This proves that education is very much essential for the women of this area in order to participate themselves in politics.

\section{CONSTITUTIONAL PROVISIONS AND POLITICS FOR WOMEN}

In odisha women constitute a very little less than $50 \%$ of the state's total population despite some favorable constitutional provisions and emergence of powerful women personalities, the position of the women is not very rosy. Their socio-economic status is very however relatively low and they are discriminated in all walks of life for centuries, women have been confined to home and suppressed and deprived of their right to get a fair treatment from the male dominated society Development of women has therefore, been one of the major issues in odisha.

The $73^{\text {rd }}$ and $74^{\text {th }}$ constitutional Amendment Act (1992) facilitated women's participation in the panchayatiraj system. These amendments have provided reservation of $1 / 3$ seats in rural and urban local bodies for women. The Govt. of Odisha has increased this reservation to $50 \%$.

All the five year plans given importance to the development of women, with a major objective of raising their economic and social status. Despite all such constitutional provisions and plans, there has been no satisfactory development in their social status. 


\section{WOMEN IN ODISHA PR SYSTEM}

Biju Patnayak the most dynamic chief minister of odisha was most emphatic about participation of women in the panchayatiraj system. He announced that for the first in the history of independent india those women will be given 33 percent reservation in the three tier panchayatiraj institution. And true to his word, he saw to it that Odisha Zilla parishad Act of 1991 and the Gram Panchayat Samiti Amendment Act of 1992 were passed by Odisha Assembly that provided for 33

Percent of reservation for women including Scheduled Caste and Scheduled Tribe women. For the first time more than 25 thousand women were elected to various Gram panchayatas, panchayat samities and Zilla parisads. It was further provided that one third of Zilla parisads would have exclusively women chairpersons. In the case of the panchayat samities and the Gram Panchayatas are of the two office- bearers, chairpersons or vice- chairpersons must be women.

Biju Patnayak also emphasized that all the elected representatives of the PRIs should receive adequate political and administrative training. It must be pointed out that odisha Government policies on reservation of women were followed by many other state government in India that culminated in the $73^{\text {rd }}$ and $74^{\text {th }}$ Amendment Acts to the constitution.

\section{PROFILE OF THE BHADRAK DISTRICT}

Bhadrak is one of the premier districts of odisha with a right heritage and history of its own. As per the legend the district has derived its name from the Goddess Bhadrakali whose temple stands on the bank of the river Salandi. The earliest inscription about the district which traced to be of $3^{\text {rd }}$ century A.D. shows that the present Bhadrakali temple was popularty knows as "parna Devati" at that time.

Bhadrak was a sub-division of Balasore district prior to its declaration as district vide Govt. of Odisha notification no. DRC-44/93-14218 Dated 27.3.1993. It came into existence on 01.04.1993. The district is bounded by Balasore district on the North, Jajpur district and river

Baitarani on the south, keonjhar distict on the west and Bay of Bengal and Kendrapada district on the East. The headquater Bhadrak town is situated $125 \mathrm{~km}$ away from the state capital, Bhubaneswar. The geographical area of the district is $2505 \mathrm{sq} \mathrm{km}$.

The district Bhadrak is constituted of one sub-division with the same name. A sub-collector is in charge of the sub-division, for the convenience of revenue administration, the district is divided into 7 Tahasils namely Bant, Bhadrak, Dhamanagar, Chandbali, Tihidi, Basudevpur and Bhondaripokhari with one Tahasildar in charge of the tahasil. For development of rural areas consisting of 1318 villages in 192 Gram Panchayats, the district is divided in to Community Development Block with one Block Development Officer incharge of each Block. The community Development Block wise number of panchayats and village is given below.

Table 4

\begin{tabular}{|c|c|c|c|}
\hline Sl.No. & Name of CD Bolcks & No. of Gram Panchayat & No. of Villages \\
\hline 1 & Bant & 22 & 206 \\
\hline 2 & Bhadrak & 31 & 150 \\
\hline 3 & Dhamanagar & 29 & 154 \\
\hline 4 & Chandbali & 33 & 292 \\
\hline 5 & Tihidi & 26 & 159 \\
\hline 6 & Basudevpur & 32 & 182 \\
\hline 7 & Bhandaripokhari & 19 & 175 \\
\hline & Total & 192 & 1318 \\
\hline
\end{tabular}

(Source: District census Handbook) 


\section{PROFILE OF THE BASUDEVPUR BLOCK}

Basudevpur is a small town located in Bhadrak district. The distance from Bhadrak to Basudevpur is approximately $35 \mathrm{~km}$ towards East from district headquarter Bhadrak. It is Tahasil headquarter. This place is the border of the Bhadrak District and Balasore District. Balasore District Simulia is west towards this place. It is near to Bay of Bengal. Basudevpur is divided into 23 wards for which elections are conducted in every 5 years. Basudevpur Municipality has population of 33,690 of which 16,927 are male which 16,763 are female as per report released by Census india 2011.

\section{EMPIRICAL STUDY}

In order to known the electoral participation of women in Gram panchayat elections. I have collected necessary data from 80 sample respondents. The first question asked was "Did you participate in the electoral process of the last panchayat election?" The table given below shows the response pattern. Participation of women in panchayat election

Table $5(\mathrm{~N}=80)$

\begin{tabular}{|l|c|c|c|c|}
\hline \multicolumn{1}{|c|}{ Question } & Yes & No & Yes & No \\
\hline $\begin{array}{l}\text { Did you participate in the electoral } \\
\text { process of the last panchayat election? }\end{array}$ & 75 & 5 & 93.75 & $6.25 \%$ \\
\hline
\end{tabular}

(Source: personal communication/ survey)

Through Gram Panchayats are created as grass root democratic institutions and election to these bodies is the first political experience for the women, there is still not $100 \%$ electoral participation of women but can be said to be more than satisfactory, it is found that $93.75 \%$ of women participated in panchayat election where as $6.25 \%$ of women remained as nonparticipant. Political awareness is the stepping stone of political participation. Awareness creates interest and interest creates involvements. So, the study investigate to what extent the women are aware about the electoral process.

Table 6 Awareness of women $(\mathrm{No}=80)$

\begin{tabular}{|c|c|c|c|}
\hline Sl.No. & Questions & $\begin{array}{c}\text { Respondents } \\
\text { saying 'Yes' }\end{array}$ & Percentage (\%) \\
\hline 1 & $\begin{array}{c}\text { Do you know that a citizen who is 18 years of } \\
\text { age can vote in the election? }\end{array}$ & 70 & $87.5 \%$ \\
\hline 2 & $\begin{array}{c}\text { Do you know that election are conducted in } \\
\text { every five years? }\end{array}$ & 74 & $92 \%$ \\
\hline 3 & $\begin{array}{c}\text { Do you know that when you are 25 years you } \\
\text { can contest election? }\end{array}$ & 40 & $100 \%$ \\
\hline 4 & $\begin{array}{c}\text { Do you know that there is a Gram panchayat in } \\
\text { your locality }\end{array}$ & 80 & $93.75 \%$ \\
\hline 5 & $\begin{array}{c}\text { Do you know that seats are reserved for women } \\
\text { in Gram Panchayat }\end{array}$ & 75 & $100 \%$ \\
\hline 6 & What is the name of your Sarapancha & 80 & \\
\hline
\end{tabular}

(Source: Personal communication/survey)

From then above table it is reveals that women have moderate and satisfactory awareness regarding the electoral process of the Gram Panchayats. They have good Knowledge about the voting age the period of elections, and the reservations of seats for women in Gram panchayats. So from this survey it is clear that long after independence of India, the women are now gaining awareness about the electoral process of the country. The present study also intends to investigate the interaction between women and the members of GPs. 
Table $7 \mathbf{m}$ Pattern of interaction between women and Gram Panchayat $(\mathrm{No}=80)$

\begin{tabular}{|c|c|c|c|c|}
\hline Sl.No. & Questions & $\begin{array}{c}\text { Regularly } \\
(\mathbf{\%})\end{array}$ & $\begin{array}{c}\text { Sometime } \\
(\%)\end{array}$ & (Never (\%) \\
\hline 1 & $\begin{array}{c}\text { Have you ever put fourth your demands } \\
\text { before the Gram panchyat? }\end{array}$ & $9(11.25 \%)$ & $11(13.75 \%)$ & $60(75 \%)$ \\
\hline 2 & $\begin{array}{c}\text { Do the Gram Panchayat of members meet } \\
\text { you? }\end{array}$ & $7(8.75 \%)$ & $15(18.75 \%)$ & $58(72.5 \%)$ \\
\hline 3 & Do you attend the meeting of Gramasava & $10(12.5 \%)$ & $21(26.25 \%)$ & $49(61.25 \%)$ \\
\hline 4 & $\begin{array}{c}\text { Do you think that yours demand are always } \\
\text { fulfilled by the Gram Panvchatyat? }\end{array}$ & $13(14.25 \%)$ & $22(27.5 \%)$ & $45(56.25 \%)$ \\
\hline
\end{tabular}

(Source: personal communication/survey)

The above table shows that the women are less satisfied with performance of the Gram Panchyat and sofar as their participation in Gram Sabha is concerned, it is very low.

\section{ANALYSIS OF THE FINDINGS}

- On the basis of the data collected from the respondents in this survey it is quite evident that some of the women rarely participate in the electoral process or the affairs of the Gram Panchayats.

- This study shows that women have moderate awareness about the electoral process.

- Some women complain that what is the need of attending Gram Sabha? In Gram Sabha particular dominate group remains active and they do what they wat.

- Their interaction with the Gram Panchayat is quite less and rarely put their demands before the Gram Panchayat about the facilities and privileges meat for them. This is because of their lack of consciousness and low level of education.

- From the above analysis it is quite obvious that a number of reasons are responsible for their apathy, less interest and indifference attitude towards political participation. The reasons are illiteracy, poverty, traditional pattern of society, narrow attitude of the members of the family and to some extent, the irresponsible and neglected attitude of the Gram Panchayat.

\section{CONCLUSION}

As the objective of this survey is concerned, it is found that participation of women in the affairs of the panchayat administration is not up the marks as compared to their male counterparts. The awareness interest and involvement in Gram panchjayat election is satisfactory. Mere inclusion of political reforms, constitutional provisions and rights are not enough; the issue is very critical, and it requires introspection by women at first hand and of course by men. It is only through a new way of thinking, a broad perspective of analysis an objective approach, a rational stream of thoughts irrespective of gender; we can think some degree of change.

\section{REFERENCES}

[1] Herbert M.C. Closky (1968)" Political Participation" in international Encyclopedia of social sciences, New York: Collier Macmillan.

[2] N. Bava (1984). Peoples participation in development administration in India, New Delhi: Uppal publisher.

[3] Panda S (1996). "Empowering pattern of leadership among rural women in Odisha", Indian journal of public administration, vol.42 No.3-4. 
[4] Mohanty, B(ed.) (2000)" Women and political Empowerment", institute of social sciences, New Delhi.

[5] Agrawal, R.C.," Women and Panchayati Raj institution" in singh J.L (ed.)" Women and panchayati Raj “. Sunrise publications,2005.

[6] Patnaik, p. (2005) "Affirmative Action and Representation of weaker sections; Participation and Accountability in Orissa's Panchayats" Economic and political weekly, October 29:4753-4761.

[7] Swain, Jharana (1994) "Emerging women leadership in panchayati Raj: A study in Balipatana Block of Khurdha District of Odisha" NIRD, Hydrabad.

[8] District census Handbook of Bhadrak, 2015. 